\title{
Implications of Ethnic Frictions and Identity Politics on Inter- Group Relations in Nigeria
}

\author{
BUHARI, Lateef Oluwafemi (PhD.) \\ Department of History and International Studies, \\ Faculty of Arts, \\ Ekiti State University, P.M.B. 5363, Ado-Ekiti, Nigeria \\ lateef.buhari@eksu.edu.ng, latfem4real@yahoo.com \\ $+2348062468125$
}

\begin{abstract}
The various ethnic groupings in Nigeria had existed before the creation of the Nigeria state in 1914 but ethnicity became politicized and its influence got heightened in the Nigeria political scene in the late 1930's. These diverse groups had their unique systems of administration and relations. The vilification of ethnicity as the scapegoat of all vices associated with the Nigerian body polity has made the subject a dominant theme in the study of Nigerian political economy. This is attached to the various sentiments opened to these various people whom existed and related before the coming of colonialism. This paper examines the composition of the various ethnic groups as well as the diverse ways in which they had related in pre-colonial times. It also pinpoint the havoc in which ethnic identity which was introduced by the colonial authority has done to the peaceful coexistence which earlier existed among the people.
\end{abstract}

\section{INTRODUCTION}

It is no more a contending fact that Nigeria is a multi-ethnic state that has over 250 ethnic groups. Despite variance perceptions on the numbers of these ethnic groups, no scholar has been able to give a definite figure of these ethnic groups.

Prior to the advent of British colonial government, there was no country called Nigeria. Each of these ethnic groups identifies, organises, coordinates and administers itself based on its traditional institutions. Aptly, this made administration simple and promotes transparency, accountability, and good governance. ${ }^{1}$

In Nigeria, most ethnic groups have district customs, traditions, and languages. The Yoruba, Igbo and Hausa/Fulani dominated the political and the larger groups. Apart from these major ethnic groups, there are other ones such as the Ijaw, Urhobo, Igala, Edo, Nupe, Kanuri, Idoma, Ebira, Efik, Junkun, Ibibio and others. It is important to note that each ethnic

\footnotetext{
${ }^{1}$ Femi Omotoso, "The Nigeria Peoples, Culture and Politics", in Essays on Nigeria Peoples, Culture and Politics (Eds.) A.A. Agagu\& Femi Omotoso (Abuja: Panaf Press, 2006), p.1.
} 
group occupies a distinct territory and most of the smaller groups had very little contact with other groups before the imposition of colonial rule. ${ }^{2}$

\section{PEOPLES AND CULTURES IN NIGERIA}

All human societies have their different cultures. Culture is an interconnected set of attitudes, feelings, and actions which have been learned and shared by a group of people. Ayodele opined that every society, from Adam, is bound together by prescribed ways of doing things and relate with others for the continuity and development of the community. ${ }^{3}$ It is important to state that the primary ingredient that cements every group together is culture. It is the soul, anchor, ability, and identity for stability and change and meaning in people's lives. Anyone could say that any nation that does not value culture has no value for history. Nigeria is rich in culture. Nigeria's rich and varied cultural heritage derives from a mixture of the traits of its different ethnic groups. ${ }^{4}$

Cultural elements include knowledge, belief, values, norms, signs, and symbols. In Nigeria, a number of cultures have developed over time, namely: Nok, Ife, Benin, and IgboUkwu cultures.

\section{HAUSA GROUP}

These people found chiefly in north-western Nigeria and adjacent southern Niger. They constitute the largest ethnic group in the area, which also contains another large group, the Fulani, perhaps one-half of whom are settled among the Hausa as a ruling class, having adopted the Hausa language and culture. The language belongs to the Chadic group of the Afro-Asiatic (formerly Hamito-Semitic) family and is infused with many Arabic words as a result of Islāmic influence, which spread during the latter part of the 14th century from the

\footnotetext{
${ }^{2}$ Ibid p. 2

3 Ayodele, J.B. "The Nigeria Cultural Heritage: Implications for Development", in A.A. Agagu and Femi Omotosho (eds) Essays on Nigerian Peoples, Culture and Politics (Abuja, Panaf Press: 2006), p.18.

${ }^{4}$ Ibid pp.18-19
} 
kingdom of Mali, profoundly influencing Hausa belief and customs. A small minority of Hausa, known as Maguzawa, or Bunjawa, remained pagan. ${ }^{5}$

Hausa society was, and to a large extent continues to be, politically organized on a feudal basis. The ruler (known as emir) of one of the several Hausa states is surrounded by a number of titled office holders who hold villages as fiefs, from which their agents collect taxes. The administration is aided by an extensive bureaucracy, often utilizing records written in Arabic.

The Hausa economy has rested on the intensive cultivation of sorghum, corn (maize), millet, and many other crops grown on rotation principles and utilizing the manure of Fulani cattle. Agricultural activity has yielded considerably more than subsistence, permitting the Hausa to practice such craft specializations as thatching, leatherworking, weaving, and silver smithing. The range of craft products is large, and trading is extensive, particularly in regularly held markets in the larger towns. Hausa is also famous as long-distance traders and local vendors of Hausa-made leather goods as well as tourist items. ${ }^{6}$

The Hausa have settled in cities (of pre-European origins, such as Kano), towns, and hamlets; but the great majority of the population is rural. A typical farm household consists of two or more men and their families grouped in a mud- or stalk-walled enclosure of some 1,000 square feet (93 square metres) containing small round or rectangular huts with thatched roofs and a larger rectangular hut in the centre for the headman of the compound.

Social structuring is markedly hierarchical; the ranking, both of offices and social classes, is expressed in an elaborate etiquette. Individuals may be ranked as commoners, administrators, or chiefs; and varying degrees of prestige attached to different professions and levels of prosperity. Slaves were formerly numerous, some of them holding important posts in the administration. Noble lineages dominated important official positions. ${ }^{7}$

\footnotetext{
${ }^{5}$ O. Ikime Ground work on Nigerian History (Ibadan Heinemann Educational Books (Nig) Ltd 1980), p. 58

${ }^{6}$ N. Okwudibia, Ethnicity and development in Nigeria, (Ashgate publishing Limited 1995), p. 121.

${ }^{7}$ O. Ikime Ground work on Nigerian History (Ibadan Heinemann Educational Books (Nig) Ltd 1980), p. 56.
} 
Descent is patrilineal; and close kin, especially cousins, are preferred marriage partners. Divorce, regulated by Muslim law, is frequent.

\section{YORUBA GROUP}

Yoruba is one of the three largest ethnic groups of Nigeria concentrated in the south-western part of the country. ${ }^{8}$ Most Yoruba men are farmers, growing yams, corn (maize), and millet as staples and plantains, peanuts (groundnuts), beans, and peas as subsidiary crops; cocoa is a major cash crop. Others are traders or craftsmen. Women do little farm work but control much of the complex market system - their status depends more on their own position in the marketplace than on their husbands' status. The Yoruba have traditionally been among the most skilled and productive craftsmen of Africa. ${ }^{9}$ They worked at such trades as blacksmithing, weaving, leather working, glassmaking, and ivory and wood carving. In the 13th and 14th centuries, Yoruba bronze casting using the lost-wax (cire-perdue) method reached a peak of technical excellence never subsequently equaled in western Africa. Yoruba women engage in cotton spinning, basketry, and dying. ${ }^{10}$

The Yoruba have shared a common language and culture for centuries but were probably never a single political unit. They seem to have migrated from the east to their present lands west of the lower Niger River more than a millennium ago. ${ }^{11}$ They eventually became the most urbanized Africans of pre-colonial times. They formed numerous kingdoms of various sizes, each of which was centred on a capital city or town and ruled by a hereditary king, or oba. ${ }^{12}$ Their towns became densely populated and eventually grew into the present-day cities of Oyo, Ile-Ife, Ilesha, Ibadan, Ilorin, Ijebu-Ode, Ado-Ekiti, and others. Oyo developed in the 17th century into the largest of the Yoruba kingdoms. Ile-Ife remained a town of potent religious significance as the site of the earth's creation according to Yoruba mythology. Oyo and the other kingdoms declined in the late 18th and 19th centuries owing to disputes among

\footnotetext{
${ }^{8}$ S. O. Johnson, History of the Yorubas. London: Lowe and Brydone printers, 1921 see also J. A. Atanda, An Introduction to Yoruba History. (Ibadan: University of Ibadan Press, 1980)

${ }^{9}$ P. C. Lloyd, The Traditional Political System of the Yoruba. South Western Journal of Anthropology, vol. 10, no. 4, 1954, see also J. A. Atanda, An Introduction to Yoruba History. (Ibadan: University of Ibadan Press, 1980)

${ }^{10}$ P. Morton-Williams, Some Yoruba Kingdoms under modern conditions. Journal of African Administration, Vol. 7, no. 4, 1955

${ }^{11}$ J. A. Atanda, An Introduction to Yoruba History. (Ibadan: University of Ibadan Press, 1980)

${ }^{12}$ K. Balogun, Government in Old Oyo Empire, Lagos: Africans publishers and co, 1985, p.64
} 
minor Yoruba rulers and invasions by the Fon of Dahomey (now Benin) and the Muslim Fulani. The traditional Yoruba kingships still survive, but with only a hint of their former political power. ${ }^{13}$

In a traditional Yoruba town the large and elaborate palace of the oba lies at the centre, and grouped around it are the compounds of the patrilineages. The palace and the compounds are now often modern structures.

There is much diversity in the social and political organization among the Yoruba, but they share many basic features. Inheritance and succession are based on patrilineal descent; members of the patrilineage live together under the authority of a headman, share certain names and taboos, worship their own deity, and have rights in lineage lands. The Yoruba also have several kinds of voluntary associations, including the Egbe, a male recreational association; the aro, a mutual-aid association of farmers; and the esusu, whose members contribute a fixed amount of money and from which they can receive loans. Political authority is vested in the $o b a$ and a council of chiefs; constituent towns each have their own ruler, who is subordinate to the $o b a$. The $o b a$ is also a ritual leader and is considered sacred. ${ }^{14}$

Many Yoruba are now Christians or Muslims, but aspects of their traditional religion survive. The traditional Yoruba religion has an elaborate hierarchy of deities, including a supreme creator and some 400 lesser gods and spirits, most of whom are associated with their own cults and priests. The Yoruba language has an extensive literature of poetry, short stories, myths, and proverbs. ${ }^{15}$

\section{IFE CULTURE}

\footnotetext{
${ }^{13} \mathrm{Oba}$ is a Yoruba term for King; an Oba is the monarchical head of government in ancient Yorubaland. Some Obas ruled supreme over their kingdoms and subjects with unchecked powers while some had checks and balances like the great Old Oyo Empire (OOE), some have their powers checked as a result of their tributary status to Old Oyo Empire. Their titles vary amongst clans in Yorubaland, for example, the Oba of Oyo is called 'Alaafin of Oyo' (Man of the palace at Oyo), some Obas' titles are attributes to their land, examples are Oluwo of Iwo, Osolo of Isolo and so forth. See also S. O. Johnson, History of the Yorubas. (London: Lowe and Brydone printers, 1921,), O. S. Osadola, Government and Political Institutions in Yorubaland up till 1886, International Journal of Humanities and Social Science Letters, 2019

${ }^{14}$ S. O. Johnson, History of the Yorubas. (London: Lowe and Brydone printers, 1921,),p. 32

${ }^{15}$ K. Balogun, Government in Old Oyo Empire, Lagos: Africans publishers and co, 1985, p.64.
} 
Oral tradition shows that Ife is the cradle of Yoruba culture and the centre of the world in general. However, the early importance of Ife may have been that it was the centre of the iron working of its time. Archaeological discoveries depict that Ife was noted for its bronze making which was said to be one of the best in that period. The terracotta figure and portrait sculpture in bronze made in Ife made it be a centre of craft specialization. Most of the archaeological pieces of evidence were discovered by chance through the efforts of Leo Frobenius, a German ethnographer.

By extension, there is a link to Benin between and Ife. The Ogiso dynasty of Benin was said to have been founded by the youngest son of Oduduwa. There is also the similarity in the art of bronze making between the two. Oral traditions say that Benin bronze got its raw materials from Ife. The Benin bronze and sculpture were world famous between the $15^{\text {th }}$ and $19^{\text {th }}$ centuries. ${ }^{16}$

\section{IGBO GROUP}

Individuals living mainly in south-eastern Nigeria communicates in Igbo, a language of the Benue - Congo part of the Niger-Congo language family. ${ }^{17}$ The Igbo might be gathered into the accompanying fundamental social divisions: northern (Onitsha), southern (Owerri), western (Ika), eastern (Cross River), and north-eastern (Abakaliki). Prior to European colonization, the Igbo were not joined as a solitary people but rather lived in self-governing nearby networks. By the mid-twentieth century, in any case, a feeling of ethnic character was firmly created, and the Igbo-ruled Eastern district of Nigeria attempted to singularly withdraw from Nigeria in 1967 as the free country of Biafra. ${ }^{18}$ By the turn of the $21 \mathrm{st}$ century, the Igbo numbered around 20 million. ${ }^{19}$

\footnotetext{
${ }^{16}$ Ulli Beier, Before Oduduwa, Odu, No 3, 1956, pp.25-32, see also O. S. Osadola, M. Ediagbonya, \& S. O. Soetan, Benin-Ekiti Relation: An Onus Of Substantiation, Global Scientific Journal, Vol. 7, Issue 2, 2019, 403414; T. Dzeka, and O. S. Osadola, Social-Cultural and Institutional Diffusion in Western Nigeria: An Assessment of Benin Influence on Ekiti, Makurdi Journal of Arts and Culture (MAJAC), Vol.13, 2015, pp. 215225 (Makurdi)

${ }^{17}$ K. Ogbaa,. "Cultural Harmony I: Igboland - the World of Man and the World of Spirits". Understanding Things Fall Apart. Greenwood Publishing. 1999, p. 106.

${ }^{18}$ B. I. Obichere. Studies in Southern Nigerian History: A Festschrift for Joseph Christopher Okwudili Anene 1918-68. Routledge. 1982, p. 207.

${ }^{19}$ B. I. Obichere. Studies in Southern Nigerian History: A Festschrift for Joseph Christopher Okwudili Anene 1918-68. Routledge. 1982, p. 208
} 
Customarily, most Igbo have been subsistence ranchers, their staples being yams, cassava, and taro. Different harvests they develop incorporate corn (maize), melons, okra, pumpkins, and beans. Among those still occupied with horticulture, men are essentially in charge of yam development, ladies for different harvests. The land is claimed collectively by family relationship gatherings and is made accessible to people for cultivating and building. Some domesticated animals, significant as a wellspring of distinction and for use in penances, is kept. The foremost fares are palm oil and palm parts. Exchanging, nearby artworks, and pay work likewise are significant in the Igbo economy, and a high education rate has helped numerous Igbo to wind up government employees and business visionaries in the decades after Nigeria picked up autonomy. It is remarkable that Igbo ladies take part in exchange and are compelling in neighbourhood governmental issues. Aside from the north-eastern gatherings, the Igbo live in rainforest nation. Most Igbo possess towns of scattered mixes, yet in certain regions towns are reduced. The compound is ordinarily a bunch of cabins, every one of which comprises a different family unit. Customarily, the town was generally involved by a patrilineage. ${ }^{20}$

Preceding the happening to British pilgrim organization, the biggest political unit was the town gathering, a league of towns averaging around 5,000 people. Individuals from the gathering shared a typical market and meeting place, a tutelary divinity, and familial cliques that upheld a custom of plummet from a typical precursor or gathering of predecessors. Expert in the town bunch was vested in a chamber of genealogy heads and powerful and rich men. In the eastern districts, these gatherings would in general structure bigger political units, including brought together kingdoms and states. ${ }^{21}$

Conventional Igbo religion incorporates confidence in a maker god, an earth goddess, and various different gods and spirits, just as a faith in precursors who ensure their living relatives. The disclosure of the desire of the gods is looked for by divination and prophets. Numerous Igbo are currently Christians. ${ }^{22}$

\section{KINSHIP INSTITUTIONS}

\footnotetext{
${ }^{20}$ A. E. Afigbo. Groundwork of Igbo history. Lagos: Vista Books. 1992, pp. 522-541.

${ }^{21}$ R. Fardon, Richard; Furniss, Graham. African languages, development and the state. Routledge. 1994 , p. 66.

22 M. P. Mathews,. (2002). Nigeria: Current Issues and Historical Background. Nova Publishers. 2002 , p. 38.
} 
Importantly, the kinship institution differentiates one town from another among the western groups and those in the north and elsewhere. This is characteristically different in the eastern part of Nigeria where decentralization was the pre-colonial trend. Patriarchal primogeniture was also common in the west and north while monarchical ascendancy in the Igbo subsection was by achievement. The cultural model of dressing was sectionally similar while gradually showing some level of distinction as the cultural line moves away into another far receding group. In religion, the pre-colonial trend was the worship of ancestors and other gods, with the arrival of the white man Christianity was introduced, but Islamic religion dominated the northern subsection of the country, having been introduced in the early part of the $15^{\text {th }}$ century. ${ }^{23}$ Western Education gradually permeated the country through the European missionaries and traders. Colonialism was not able to impact ethnic unity and since independence, there is ethnic disunity and unacceptance. This has continued to affect the polity of the state.

\section{INTER-GROUP / ETHNIC RELATIONS BEFORE CONTACT WITH EUROPEANS}

Contrary to the widely held notion that the peoples of Nigeria had nothing in common prior to the country of Europeans, there are plethora of evidences that depict that from time immemorial, the forefathers of the people who today inhabit Nigeria inter-related in many spheres of life, especially through trade, migrations, marriage, religion, and war. These contacts brought the various groups into close contact and understanding with one another. ${ }^{24}$

Trade: This was the most pronounced and one which brought the various groups and communities into closer cooperation. Inter-tribal and inter-regional trade transverse the length and breadth of the Nigerian territory. Prof. Afigbo as cited by Emmanuel Ojo opined four distinct trade routes that linked the Igbo with their immediate neighbours; these include the Igala, Idoma, Ogoja, Effik, Ibibio, Ijaw and Edo. The northward route moved to Igala and Idoma and was serviced by the Akwans Nri while the Aro and the Nsukka people played

\footnotetext{
${ }^{23}$ A. E Afigbo. Groundwork of Igbo history. Lagos: Vista Books. 1992, pp. 522-541.

${ }^{24}$ Emmanuel, O.O. Selected Themes in Nigerian History (Ibadan, King Julius Educational publishers: 2006), p. 51
} 
a part. The Igbo carried to these places metal implements like hoes, made by the Akwa, Medicines and ritual ceremonies, glass beads, caps and other apparels (cloths). ${ }^{25}$

However, in those days, trade depended on the geographical area of production. The Niger wards routes moved to Edo from where the Igbo got agricultural produced, slaves and salt which they imported from the Ijaw (a riverine area). There were also eastward routes which moved to Cross River. The Igbo moved slaves to this place, agricultural produce, dried meat and from there, they bought European goods. The fourth route was the southward route which moved to the coast where salt and fish were exchanged for agricultural produce and manpower from Igboland. ${ }^{26}$

The trade contact between north and Yoruba-land during this period as explained by Prof. Atanda depicts that the north supplied horses which the Oyo built their cavalry in exchange for Oyo Kola. Items between these communities or groups show that trade between the south and north has an ancient origin. Both Yoruba and Benin traditions recorded extensive contacts between the two groups through the lagoon from Lagos to the Niger Delta and through overland route from Ekiti area, Eastern Yoruba land traded extensively with Nupe in the North and Benin in the South.

Migrations and Peopling: Most traditions of origin create the impression of a mixture of crops along the migration routes, leading eventually to heterogeneous settlements. The Ijaw people, for instance, claimed that as they were migrating, the mixed up with the Igbo group and inter-married with them. The off-springs of such marriages had Igbo and Ijaw blood.

Similarly, Ibibio claim that while migrating, they settled at Ibom at Arochukwu (probably about 800 BC.) where they established the shrine known as the Long Juju. ${ }^{27}$ From this location, they spread to the Ibibio mainland while others remained before they were expelled by the Aro, through warriors. The claims from Tiv stated that they came down to their present country from the hilly district of the south-east where they lived together in one large community before they were attacked by enemies. While going down from the hills to the plains, they came in contact with Fulani and formed a close friendship. Tradition shows

${ }^{25}$ Emmanuel, O.O. Selected Themes in Nigerian History (Ibadan, King Julius Educational publishers: 2006), p. 51

26 O. N. Njoku,. Pre-colonial economic history of Nigeria. Ethiope Publishing Corporation, Benin City, Nigeria. 2002

27 Emmanuel, O.O. Selected Themes in Nigerian History (Ibadan, King Julius Educational publishers: 2006), p.53 
that they also came into contact with Hausa groups, Jukun and Chamba and borrowed some of their cultures. They learned to weave from Hausa, Tiv people learned blacksmithing from the Chambas and obtained political institutions from the Jukun group.

Also, Igala is another prominent group in Nigeria. By its strategic position in Central Nigeria, the Igala came into contact with many Nigerian groups including the Igbo, Edo, Yoruba, Nupe, Idoma, Tiv and Jukun. The area became a meeting point for many Nigerian groups. From these migration processes, it is clear that pre-colonial Nigerian peoples had extensive contacts with one another. ${ }^{28}$

War: In African traditional societies, the war was a continuation of relations order than diplomatic means. In the case of Nigeria, every Nigerian group fought wars with one or more groups. These wars did not only caused dislocation or destruction as a continuation of relations order than diplomatic means. The war intensified contacts in many ways: The language of the people with whom a community was fighting, a war had to be learned to aid fighting. This knowledge did not die at the end of the war but survived and became a means of greater understanding and such peoples or groups. Also, the mode of dressing of the enemy had to be copied as camouflage culture. And, those engaged in the war had to travel outside their own homes to the neighbouring territories in search of allies, medicine men and weapons. Alliance formed during this period had been known to last even after the war. The successful wars integrated many districts. Examples of political entities which were brought together by wars were big empires: Benin, Oyo, Nupe, Jukun and the Kauri which made up of diverse peoples. ${ }^{29}$

Religion: In the religious sphere, there were many contacts, some of which had political overtures. From the $13^{\text {th }}$ century, Islam became a religion which spread across communities and which brought such communities into obedience to whoever was appointed the Amir-alMummin (Commander of the faithful).

Religion just as the various Nigerian peoples inter-related in several areas of life, they built for themselves strong economies through which their material, physical and financial needs were met.

\footnotetext{
${ }^{28}$ J. O. Aremu, and F. M. Adu,. "The Study of Nigerian History" in C.T. Oluwadare, I.A. Ajayi and L.B. Ajayi, Nigerian Peoples and Culture (eds). (Ibadan: Niyi Comm. and Printing Ventures, 2017), p.05.

${ }^{29}$ O. S. Osadola, "Warfare and Diplomacy the Pre-colonial Ekiti land," International Journal of Humanities and Social Science Letters, 2019. See also, Emmanuel, O.O. Selected Themes in Nigerian History (Ibadan, King Julius Educational publishers: 2006), p.51
} 


\section{THE BIRTH OF NIGERIA AS A GEOGRAPHICAL ENTITY}

Nigeria lies roughly between latitudes $4^{0} \mathrm{~N}$ and $14^{0}$ North of the equator. It is surrounded by French-speaking West African States except in the South, where it is bordered by the Atlantic Ocean. ${ }^{30}$

The elongated territory of Benin lies to the West, the semi-arid country of the Niger Republic to the North and sub-equatorial Cameroon to the East. Nigeria has a total area of 923,700 square kilometers. Nigeria is blessed with many natural resources such as gold, bitumen, limestone, tin columbine, kaolin, silver, coal, lead, zinc, gypsum, clay, shale, marble, graphite, iron ore, stone, silicon, natural gas and crude oil amongst others. Interestingly, the country is blessed with a geographic advantage of two large Rivers (rivers Niger and Benue), rich in fish and aquatic life and terminating into the Atlantic Ocean to form a spread of the largest delta fan in Africa. The Nigerian Niger Delta is the second largest wetland is made up of mangrove swamps and low lying alluvial plants; it is one of the richest in water resources worldwide. Other notable rivers include Anambra, Imo, Benin, Ogun, etc.

Aremu and Adu noted that by 1960, Nigerian population was estimated to be about 52 million, in 1963, it grew to 55.7 million, while in 1991, it was projected to be about 88 million by the National Population Commission of Nigeria. It was reviewed in 1997 and put at 88.9 million. By the year 2000, further projections estimated 165 million and 180 million for 2015. As presort, the annual population growth rate estimate has been put at 3.3 percent. ${ }^{31}$ Nigeria is no doubt the most populous African country with the largest concentration of black people in the world.

It is apt to say that Nigeria was no always one country as it is today. In the heat of modern politics in Nigeria, the leaders of the various ethnic groups which constitute presentday Nigeria naturally take the existence of these groups for granted. It is almost as if these peoples of Nigeria have always been identified as Igbo, Hausa, Yoruba, Efik, etc. Yet we know that these peoples did not begin to identify themselves in these terms until the emergence of the colonial state of Nigeria. Indeed, it would be right to note that it was

\footnotetext{
${ }^{30}$ I. A. Eluwa, et al. History of Nigeria (South West Province: Africa-First Publishers, 1988) P. 208.

${ }^{31}$ J. O. Aremu, and F. M. Adu,. "The Study of Nigerian History" in C.T. Oluwadare, I.A. Ajayi and L.B. Ajayi, Nigerian Peoples and Culture (eds). (Ibadan: Niyi Comm. and Printing Ventures, 2017), p.05.
} 
European visitors, traders, and writers, who first began to refer to whole conglomerates terms of the language they speak. ${ }^{32}$

When aliens referred to the Igbo, they meant those who speak the language, not a single politically coherent group. Nigerian ethnic groups are thus eventually linguistic and cultural groups that have been increasingly forced by circumstances of history to act politically in defiance of their interests' vis-à-vis the interests of another competing group in what we now know as Nigeria. Until the emergence of the colonial state of Nigeria, then, what we had were myriads of groups, some of which spoke different forms of the same language and possessed certain common cultural traits. ${ }^{33}$

Nigeria was formerly made up of various states, empires, and kingdoms. The largest and most influential of these was the Fulani Empire, popularly referred to as the Sokoto caliphate which extended over most of Northern Nigeria in the nineteenth century. In the more forested South, where the Fulani cavalry could not easily penetrate, were the Oyo and Benin Empires. East of the Niger lived the Igbo and Ibibio communities who had their own unique system of political organizations.

As a result of British annexation of the territory, the country, Nigeria came into being in 1914 when the then Northern and Southern protectorates were amalgamated by Lord Frederick Lugard. Nigeria attained political independence on 1 October 1960 as a federation made up of three regions. In 1963, she became a Republic. Despite this, however, the struggle to nationhood, after political sovereignty continues, wars are being fought against imperialism, neo-colonialism, illiteracy, tribalism, nepotism, selfishness and greediness. There however good indication that the emergence of a national identity is in sight. ${ }^{34}$

\section{POLITICAL FRICTIONS IN NIGERIA AND THE SEARCH FOR A STABLE SOCIO-POLITICAL ORDER}

By 1960, most the African states had become politically independent. Our dear country, Nigeria, is one of them having gained independence on October 1, 1960, from the British Colonial authority. In most of these African countries, hardly had the flags of the erstwhile colonial rulers been lowered than political instability ensued. The rapidity with

\footnotetext{
${ }^{32}$ T. Falola, et al History of Nigeria 3: Nigeria in the nineteenth Century (Enugu: Longman; 1991) p. 20

${ }^{33}$ T. Falola, et al. History of Nigeria 3: Nigeria in the nineteenth Century (Enugu: Longman; 1991) p. 21

${ }^{34}$ Evolution of Nigeria, 1849-1960. http://www.onlinenigeria.com/history. Retrieved 1/9/18
} 
which political instability engulfed these states has been and still is, a major source of concern to historians and political observers.

Now, what are the roots causes of political frictions in Nigeria?

What are the conditions necessary for political frictions in the country?

A number of factors may be held responsible for the problem of political instability in Nigeria. ${ }^{35}$

Heterogeneous ethnic composition and the resultant problem of ethnicity: One of the most politically sensitive areas of social life in Africa is ethnicity and inter-ethnic relations. Nigeria is made up of numerous ethnic groups numbering to over 250 groups.

Three of these are however dominant - the Yoruba, the Ibo, and the Hausa-Fulani. Some of these groups had, for centuries, experienced various degrees of intermingling, strong ethnic loyalties survived. This had led to the problem of ethnicity which is expressed in the scramble for various posts and promotions in the civil service, competition for job opportunities and Federal appointments in parastatals' boards. Ethnic affiliations rather than merit have been the major criteria used in these situations to the effect that in Nigeria today, you get what you want not on the basis of what you know but whom you know. ${ }^{36}$

So, people tend to see themselves first as Yoruba, Ibo or Hausa and later as Nigerians. All these factors had led to feelings of suspicion, hatred as distrust among members of the various ethnic groups in Nigeria and have retarded political integration.

i. Education Imbalance: It is one of the major factors militating against political stability in Nigeria. There are disparities in educational development between the Northern and Southern Nigeria. This inequality has been at the centre of the North-South dichotomy in Nigerian politics till date. It has created a superiority-inferiority complex between the two parts of the country. The consequences of this have been distrust, suspicion and despite. These feelings can best be understood in words of Imam Abubakar as cited by Aremu:

We (Northerners) despise each other, we call each other ignorant; the South is proud of western knowledge and culture; we are proud of Eastern (culture) ... to tell you the truth, the

\footnotetext{
35 J. U. Nwachukwu,. Ethnic Politics and Haegemony: An Appraisal of Colonial And Post Colonial Nigeria. Intellectual Archive, Canada, 2019

${ }^{36}$ S. Folarin, "Ethnicity and power politics: From June 12 to Boko Haram", National Mirror, August 15, 2012, p. 18
} 
common people of the North put more confidence on the white man than their black southern brothers... ${ }^{37}$

The above comment therefore socially disorientated and alienated the peoples of Nigeria and is seriously affecting political stability.

ii. Religious Impatience: The problem of religious impatience is another obstacle to political stability in Nigeria i.e. unwillingness to recognize and respect differences in opinions or belief of other groups. Nigeria is a secular - state - a multi-religious state, relatively divided geographically with the Northern part being predominantly Muslim and Southern having a near parity of Christian and Muslim population. ${ }^{38}$ If the religious intolerance between Muslim and Christian in Nigeria continues this way, there will be no peace and unity in the country.

It is apt to say that fundamental differences in religion, especially between Muslims and Christians, has accounted for the problem of religious intolerance.

The enlistment of Nigeria into O.I.C. in the year 1986 also generated into religious crisis and disturbances in the country. It resulted into suspicion between adherents of these religions.

The facts, therefore, remain that such a tense and unpeaceful atmosphere, with a threat to lives and properties, can never make for unity and stability in a polity. ${ }^{39}$

\section{iii.Inequalities in size and population of political institutions at independence: Another} important issue that led to the problem of political instability in Nigeria was the nature of the administrative and political institutions that were transferred to Nigeria at independence. Regions in Nigeria were: Northern, Eastern and Western Regions. The appealing point to note about these regions was their unequal sizes.

The Northern region above was larger than the eastern and western regions combined. The 1953-1954 census figures indicated that the North accounted for 70 percent of the territory of the country and 55 percent of its population. One of the consequences of this is that the North has always sought to dominate others, and even seen the political leadership as its "birth-

\footnotetext{
${ }^{37}$ Aremu, J.O. Introduction to Nigerian History, (unpublished, 2001) p. 13 see also, J. U. Nwachukwu,. Ethnic Politics and Haegemony: An Appraisal of Colonial And Post Colonial Nigeria. Intellectual Archive, Canada, 2019

${ }^{38}$ Aremu, J.O. Introduction to Nigerian History, (unpublished, 2001) p. 13

${ }^{39}$ S. Folarin, "Ethnicity and power politics: From June 12 to Boko Haram", National Mirror, August 15, 2012, p. 18
} 
right". This is generating some tensions in the aggrieved regions to unseat the dominant region and may even be said to account for the "inevitability of instability" in Nigerian politics. $^{40}$

iv. The Minority Problem: The problem of minorities in Nigeria has also been a great source of instability. The minorities in each of the regions/states are usually in doubt of their role in a society where an entrenched majority could perpetuate its power and make any democratic change of government impossible. The minority group also feared that they would be discriminated against in employment and in the distribution of other amenities.

Since 1951, minority grievances have been so strong that agitation for states creation followed. Strained relations between the minority and the majority groups have continued to be a source of instability in Nigerian politics and the distribution of resources. The creation of more states in Nigeria over the years has not solved the problem. The last time that more states were created was under the late Head of State General Sani Abacha on $1^{\text {st }}$ October 1996. Namely: Ekiti, Ebonyi, Bayelsa, Nasarawa, Zamfara, and Gombe. ${ }^{41}$

v. Poverty: This is another major problem of political instability in Nigeria. The average per-capita income of Nigerians ranks among the lowest in the world. The standard of living of Nigerians is very low. Such a poor citizenry cannot support a lasting democracy and stability. Hence, it has promoted corruption among public office holders and thuggery among the Nigerian youths. This has been militating against stability.

vi. Economy: At Independence in 1960, Nigeria opened up with an agro-based economy. Cash crop was the mainstay of the economy. Cocoa was majorly produced in the western Yoruba, while palm oil was dominated by the Igbo in the eastern subsection. The Groundnut pyramids were the historical pride of Northern Nigeria. Foreign exchange from these items held sway to other international currencies without much ado. This gradually changed with the discovery of Petroleum in Oloibiri in Bayelsa State. Petrodollar became the architect of economic troubles as the nation lost the forefront position in agricultural production with the advent of oil wealth.

Anyanwu recorded that, prior to July 1986, Nigeria operated a mixed economy in which government owned and ran most public enterprises, in addition to mining iron and

\footnotetext{
${ }^{40}$ S. Folarin, "Ethnicity and power politics: From June 12 to Boko Haram”, National Mirror, August 15, 2012, p. 20

${ }^{41}$ Aremu, J.O. Introduction to Nigerian History, (unpublished, 2001) p. 15
} 
steel. As a consequence to the borrowing of the loan from the World Bank, the IMF-World Bank instituted Structural Adjustment Programme in July 1986, introduced privatization of public enterprises and those not privatized were commercialized. ${ }^{42}$

The conditions necessary for socio-political stability in Nigeria are the promotion of a high sense of discipline; formulation of a national ideology; improvement in the standard of living through economic development and quality of leadership (patriotic leaders).

\section{Conclusion}

An inter-ethnic relation is a burning issue in the political and social spheres in Nigeria. Ethnic mixtures-more pronounced in big cities-which were already present in the commercial stage of Nigeria's economic development, are becoming much more evident now since Nigeria is undergoing a series of industrialization. Industry usually attracts immigrants, and industrial firms are a focus of inter-ethnic contacts within the towns and cities.

It is important to state that we Nigerians like to be referred to as Ekitis, Efiks, Fulanis, Binins, Gwaris, Hausas, Ibibios, Ibos, Igalas, Idomas, Igbiras, Ijaws, Itsekiris, Kalabaris, Kanuris, Nupes, Ijeshas, Ogonis, Tiv, Western Ibos, and Yorubas. ${ }^{43}$

\footnotetext{
42 Anyanwu, J.C. The Structure of the Nigerian Economy: 1960-1997, Joanne Educational Publishers Ltd. Onitsha, Nigeria, (1997)

${ }^{43}$ Sanda, A.O. "The Ethnic Factor in Urban Social Relations" in Sanda, A.O. (eds) Ethnic Relations in Nigeria. Pp. 175-191.
} 